\title{
Megistoquinones I and II, Two Quinoline Alkaloids with Antibacterial Activity from the Bark of Sarcomelicope megistophylla
}

\author{
Nikolas Fokialakis, ${ }^{a}$ Prokopios Magiatis, ${ }^{a}$ Ioanna Chinou, ${ }^{a}$ Sofia Mitaku, ${ }^{* a}$ and François Tillequin ${ }^{b}$ \\ Laboratory of Pharmacognosy, Department of Pharmacy, University of Athens, ${ }^{a}$ Panepistimiopolis, Zografou, GR-15771 \\ Athens, Greece and Laboratoire de Pharmacognosie de l'Université René Descartes, ${ }^{b}$ UMR/CNRS N ${ }^{0}$ 8638, Faculté des \\ Sciences Pharmaceutiques et Biologiques, 4 avenue de l'Observatoire, F-75006 Paris. \\ Received September 10, 2001; accepted December 4, 2001
}

\begin{abstract}
Two alkaloids, megistoquinone I (1) and megistoquinone II (2), were isolated from the bark of Sarcomelicope megistophylla. Their structures have been elucidated on the basis of MS and NMR data. Both belong to quinoline alkaloid series and should be considered as oxidation products of a furo[2,3-b]quinoline precursor. The two alkaloids showed antibacterial properties with minimum inhibitory concentration (MIC) ranging from 2.35 to $5.25 \mathrm{mg} / \mathrm{ml}$ for 1 and 0.73 to $1.23 \mathrm{mg} / \mathrm{ml}$ for 2 .
\end{abstract}

Key words quinolone; alkaloid; antibacterial; Sarcomelicope megistophylla; Rutaceae

Sarcomelicope megistophylla HARTLEY (Rutaceae) is a small to medium sized tree, endemic to the region of Néaoua, New Caledonia. ${ }^{1)}$ Recently, we described the chemical constituents of its leaves ${ }^{2)}$ and the major alkaloids of the bark. ${ }^{3)}$ In a continuation of our studies of the genus Sarcomelicope, ${ }^{4}$ we report here the isolation and structure determination of two alkaloids, megistoquinone I (1) and megistoquinone II (2) from the bark of Sarcomelicope megistophylla. Both of them derive from a quinoline basic skeleton.

Megistoquinone I (1) was obtained as a yellow amorphous compound, and its molecular formula was determined by high resolution (HR)-MS as $\mathrm{C}_{13} \mathrm{H}_{9} \mathrm{NO}_{5}$. The ${ }^{1} \mathrm{H}-,{ }^{13} \mathrm{C}-\mathrm{NMR}$, and heteronuclear multiple bond coherence (HMBC) (Fig. 1) spectra agreed with structure 1, corresponding to that of a $p$ quinone derived from the furo[2,3-b]quinoline basic skeleton. Compound $\mathbf{1}$ had been previously obtained by Lahey et $a l .{ }^{5)}$ by nitric acid oxidation of acronycidine, in the course of a series of degradation experiments which led to the structure elucidation of this latter alkaloid. Reproduction of this reaction permitted to confirm the identity of megistoquinone I, which is isolated here for the first time from a natural source. Previous characterization of this compound only relied on melting point and elemental analysis to which we now add MS, UV, IR, and NMR spectroscopic data.

Megistoquinone II (2) was obtained as a purple amorphous compound, and its molecular formula was determined by HR-MS as $\mathrm{C}_{14} \mathrm{H}_{13} \mathrm{NO}_{6}$. From the IR spectrum ( $v=1643$, $\left.1625 \mathrm{~cm}^{-1}\right)$, it was obvious that this molecule also contained in its structure a $p$-quinone system. The ${ }^{1} \mathrm{H}-\mathrm{NMR}$ spectrum indicated two conjugated olefinic protons, three $\mathrm{OCH}_{3}$ groups (all placed on $s p^{2}$ carbons), one aromatic proton $(\delta$ 5.94) and one $\mathrm{N}-\mathrm{H}$ group (broad singlet at $\delta 9.53$ ). As in the case of 1 the ${ }^{13} \mathrm{C}$-NMR spectrum confirmed the above observations and showed the presence of two carbonyl groups, corresponding to a $p$-quinone system $(173.8,181.2)$ but also an additional carbonyl group (160.3). It also showed the<smiles>COc1cc(=O)c2c(OC)c(=O)c(=O)c(=O)c-2nc1=O</smiles><smiles></smiles><smiles></smiles>

presence of five quaternary aromatic carbons, and three protonated olefinic or aromatic carbons. The five quaternary aromatic carbons together with the three carbonyl groups and one protonated aromatic carbon constituted a quinolone ring.

From the HMBC spectrum (Fig. 1) it was clear that the $\mathrm{OCH}_{3}$ group at $3.85 \mathrm{ppm}$ was correlated with an aromatic carbon at $158.2 \mathrm{ppm}$, which was identified as C-4 by its ${ }^{3} J$ correlation with the olefinic proton H-9. That proton was also correlated with the carbonyl carbon $\mathrm{C}-2$, confirming the placement of the side chain at C-3. That carbon was identified by its ${ }^{3} J$ correlation with the second olefinic proton $\mathrm{H}-$ 10. The carbon bearing this proton $(\mathrm{C}-10)$ was correlated with the $\mathrm{OCH}_{3}$ group at $3.80 \mathrm{ppm}$, completing the structure of the side chain. As in the case of $\mathbf{1}$, the last $\mathrm{OCH}_{3}$ group (3.89) showed a nOe correlation with the aromatic singlet (H-6), which additionally showed a weak ${ }^{2} J$ correlation with the carbonyl carbon C-5 and two ${ }^{3} J$ strong correlations with the carbonyl carbon $\mathrm{C}-8$ and with the bridge carbon $\mathrm{C}-4 \mathrm{a}$ (110.8). The only carbon that did not show any correlation in the HMBC spectrum was the carbon at 145.2 , which was assigned to C-8a. Finally the stereochemistry of the double bond of the side chain was found to be trans, due to the absence of nuclear Overhauser effect (NOE) correlation between the two olefinic protons and the observation of NOE correlation of those two protons with the $\mathrm{OCH}_{3}$ group of $\mathrm{C}$ 10.

From a biogenetic point of view, megistoquinone I (1) most probably arises from the oxidation of the benzene aromatic ring of a furo[2,3-b]quinoline precursor, such as acronycidine (3), which is one of the major alkaloids isolated from the bark. ${ }^{4}$ Megistoquinone II can be further considered to derive from the hydrolysis of the furan ring of megistoquinone I, regarded as a vinyl ether, followed by methylation
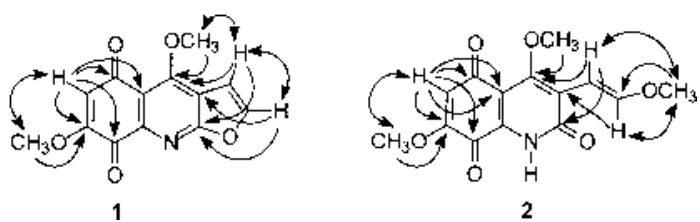

Fig. 1. HMBC $(\rightarrow)$ and NOESY $(\leftrightarrow)$ Correlations for Megistoquinone I (1) and Megistoquinone II (2) 
Table 1. Antibacterial Activity of Tested Compounds $\mathbf{1}-\mathbf{3}(\mathrm{MIC} \mathrm{mg} / \mathrm{ml})$

\begin{tabular}{|c|c|c|c|c|c|c|}
\hline Tested compounds & S. aureus & S. epidermidis & P. aeruginosa & E. cloacae & K. pneumoniae & E. coli \\
\hline 1 & 2.35 & 2.77 & 3.24 & 3.12 & 5.25 & 4.75 \\
\hline 2 & 0.75 & 0.73 & 0.97 & 0.89 & 1.23 & 1.02 \\
\hline 3 & $>20$ & $>20$ & $>20$ & $>20$ & $>20$ & $>20$ \\
\hline Netilmicin & $4 \times 10^{-3}$ & $4 \times 10^{-3}$ & $8.8 \times 10^{-3}$ & $8 \times 10^{-3}$ & $8 \times 10^{-3}$ & $10 \times 10^{-3}$ \\
\hline Amoxycillin & $2 \times 10^{-3}$ & $2 \times 10^{-3}$ & $2.4 \times 10^{-3}$ & $2.8 \times 10^{-3}$ & $2.2 \times 10^{-3}$ & $2 \times 10^{-3}$ \\
\hline Clavulanic acid & $0.5 \times 10^{-3}$ & $0.5 \times 10^{-3}$ & $1 \times 10^{-3}$ & $1.6 \times 10^{-3}$ & $1 \times 10^{-3}$ & $1.2 \times 10^{-3}$ \\
\hline
\end{tabular}

of the resulting enol.

The antibacterial activity of compounds $\mathbf{1 ,} 2$ and $\mathbf{3}$ was evaluated two gram positive and four gram negative bacteria (Table 1). Megistoquinone II (2) was found to be more active than megistoquinone I (1) with minimum inhibitory concentration (MIC) ranging from 0.73 to $1.23 \mathrm{mg} / \mathrm{ml}$ for 2 and 2.35 to $5.25 \mathrm{mg} / \mathrm{ml}$ for $\mathbf{1}$. Both compounds were more active against the gram positive bacteria. Interestingly, their biogenetic precursor, acronycidine (3), was totally inactive, revealing the significance of the $p$-quinone system in the antibacterial activity of this class of compounds.

\section{Experimental}

General Experimental Procedures UV spectra were recorded on a Shimadzu-160A spectrophotometer. The IR spectrum was obtained on a Perkin-Elmer Paragon 500 instrument. NMR spectra were recorded on Bruker DRX 400 and Bruker AC 200 spectrometers $\left[{ }^{1} \mathrm{H}(400,200 \mathrm{MHz})\right.$, $\left.{ }^{13} \mathrm{C}(50 \mathrm{MHz})\right]$; chemical shifts are expressed in ppm downfield to TMS. The two-dimensional (2D) NMR experiments were performed using standard Bruker microprograms. Electron impact (EI)-MS and HR-MS were determined on HP-6890 and AEI MS-902 spectrometers, respectively.

Plant Material The plant material was collected at Néaoua (New Caledonia) in May 1984. A Voucher sample (Pusset-Chauvière 261) is kept in the herbarium of the Centre ORSTOM at Nouméa (New Caledonia).

Extraction and Isolation Extraction of alkaloids was as described. ${ }^{3)}$ The crude alkaloid mixture was fractionated over a column containing Si gel (Merck 0.04-0.06 mm; flash), using a cyclohexane/EtOAc gradient. The fractions containing the new alkaloids were resubmitted to flash chromatography on silica gel with $\mathrm{CH}_{2} \mathrm{Cl}_{2}$ to afford megistoquinone $\mathrm{I}(5 \mathrm{mg})$ and megistoquinone II (12 mg).

Megistoquinone I (1): ${ }^{1} \mathrm{H}-\mathrm{NMR}\left(\mathrm{CDCl}_{3}, 400 \mathrm{MHz}\right) \delta: 7.79(1 \mathrm{H}, \mathrm{d}$, $J=2.6 \mathrm{~Hz}, \mathrm{H}-2), 7.16(1 \mathrm{H}, \mathrm{d}, J=2.6 \mathrm{~Hz}, \mathrm{H}-3), 6.10(1 \mathrm{H}, \mathrm{s}, \mathrm{H}-6), 4.41(3 \mathrm{H}, \mathrm{s}$, $\mathrm{OMe}-\mathrm{C} 4), 3.86(3 \mathrm{H}, \mathrm{s}, \mathrm{OMe}-\mathrm{C} 7) .{ }^{13} \mathrm{C}-\mathrm{NMR}\left(\mathrm{CDCl}_{3}, 50 \mathrm{MHz}\right) \delta: 183.5(\mathrm{C}-$ 5), 178.0 (C-8), 164.6 (C-9a), 161.9 (C-4), 158.8 (C-7), 147.1 (C-2), 145.4 (C-8a), 114.9 (C-4a), 111.8 (C-6), 111.2 (C-3a), 108.4 (C-3), 60.6 (OMe-C4), 56.8 (OMe-C7). IR $\left(\mathrm{CH}_{2} \mathrm{Cl}_{2}\right) \mathrm{cm}^{-1}: 1692,1647,1624,1575$, 1464, 1305. UV $\lambda_{\max }(\mathrm{MeOH}) \mathrm{nm}(\log \varepsilon): 371$ (3.37), 291 (sh), 258 (4.23). MS-DCI $m / z: 260[\mathrm{M}+\mathrm{H}]^{+}$. EI $m / z$ (rel. int): 259 (36), 242 (50), 230 (100), 202 (27). HR-EI-MS $m / z$ : 259.0477; Found for $\mathrm{C}_{13} \mathrm{H}_{9} \mathrm{NO}_{5}$; required $m / z$ : 259.0481 .

Megistoquinone II (2): ${ }^{1} \mathrm{H}-\mathrm{NMR}\left(\mathrm{CDCl}_{3}, 400 \mathrm{MHz}\right) \delta$ : $9.53(1 \mathrm{H}$, brs, $\mathrm{N}-\mathrm{H}), 8.42(1 \mathrm{H}, \mathrm{d}, J=12 \mathrm{~Hz}, \mathrm{H}-10), 6.19(1 \mathrm{H}, \mathrm{d}, J=12 \mathrm{~Hz}, \mathrm{H}-9), 5.94(1 \mathrm{H}$, s, H-6), $3.89(3 \mathrm{H}, \mathrm{s}, \mathrm{OMe}-\mathrm{C} 7), 3.85(3 \mathrm{H}, \mathrm{s}, \mathrm{OMe}-\mathrm{C} 4), 3.80(3 \mathrm{H}, \mathrm{s}$, OMe-C10). ${ }^{13} \mathrm{C}-\mathrm{NMR}\left(\mathrm{CDCl}_{3}, 50 \mathrm{MHz}\right) \delta: 181.2(\mathrm{C}-5), 173.8(\mathrm{C}-8), 160.3$ (C-2), 158.2 (C-4), 157.9 (C-10), 156.7 (C-7), 145.2 (C-8a), 110.8 (C-4a), 109.0 (C-6), 96.9 (C-9), 61.0 (OMe-C4), 57.6 (OMe-C10), 56.5 (OMe-C7). IR $\left(\mathrm{CH}_{2} \mathrm{Cl}_{2}\right) \mathrm{cm}^{-1}: 3360,1643,1625,1512,1455,1236$. UV $\lambda_{\max }(\mathrm{MeOH})$ $\mathrm{nm}(\log \varepsilon): 515$ (2.33), 315 (sh), 278 (3.54). MS-DCI m/z: $292[\mathrm{M}+\mathrm{H}]^{+}$. MS-EI $m / z: 291\left(\mathrm{M}^{+}\right), 276,260,248,220$. HR-EI-MS $m / z: 291.0746$; Found for $\mathrm{C}_{14} \mathrm{H}_{13} \mathrm{NO}_{6}$; required $m / z$ : 291.0743 .

Antibacterial Test The in vitro antibacterial activity of the tested compounds was determined by the dilution method of Bauer-Kirby) as it has been described in details previously ${ }^{7}$ against two gram positive bacteria: Staphylococcus aureus (ATCC 25923), and Staphylococcus epidermidis (ATCC 12228), and four gram negative: Pseudomonas aeruginosa (ATCC 27853), Escherichia coli (ATCC 25922), Enterobacter cloacae (ATCC 13047), Klebsiella pneumoniae (ATCC 13883). Serial dilutions of the stock solutions in broth medium (100 $\mu \mathrm{l}$ of Muller-Hinton broth) were prepared in a microtiter plate (96 wells). Then $1 \mu \mathrm{l}$ of the microbial suspension (in sterile distilled water) was added to each well. For each strain, the growth conditions and the sterility of the medium were checked and the plates were incubated as it has been referred above. MICs were determined as the lowest concentrations preventing visible growth. Standard antibiotics (netilmicin, amoxicillin and clavulanic acid) were used in order to control the sensitivity of the tested bacteria.

Acknowledgment Dr. T. Sévenet (ICSN/CNRS, Gif-sur-Yvette, France) is gratefully acknowledged for his kind interest in this work.

\section{References and Notes}

1) Hartley T. G., "Bulletin du Museum National d'Histoire Naturelle," Paris, 4ème Sér. Section B, Adansonia, 8, 183-189 (1986).

2) Fokialakis N., Mitaku S., Mikros E., Skaltsounis A. L., Tillequin F., Sévenet T., Phytochemistry, 52, 1745-1748 (1999).

3) Papageorgiou M., Fokialakis N., Mitaku S., Skaltsounis A. L., Tillequin F., Sévenet T., J. Nat. Prod., 63, 385-386 (2000).

4) Fokialakis N., Magiatis P., Terzis A., Skaltsounis A. L., Tillequin F., Tetrahedron Lett., 42, 5323-5325 (2001).

5) Lahey F. N., Lamberton J. A., Price J. R., Austral. J. Scient. Res., 3, 155-167 (1950).

6) Cruickshank R., Duguid I. P., Marmion B. P., Swain R. H. A., "Medical Microbiology," Vol. 3, 12nd edn. Churchill Livingstone, Edinburgh, 1975 .

7) Magiatis P., Melliou E., Skaltsounis A. L., Chinou I., Mitakou S., Planta Med., 65, 749-752 (1999). 